\title{
Comparación entre el pronóstico de corrosión basado en la medición de potenciales y la determinación de la velocidad de corrosión de la barra de refuerzo mediante técnicas electroquímicas
}

\section{Comparison between the corrosion forecast based on the potential measurement and the determination of the corrosion rate of the reinforcement bar by means of electrochemical techniques}

A. CASTAÑEDA, F. CORVO, V. O'REILLY(*)

Dpto. Corrosión, Centro Nacional de Investigaciones Científicas (CNIC). La Habana

("Ministerio de la Construcción, La Habana

Fecha de recepción: 14-I-03

Fecha de aceptación: 5-VI-03

CUBA

\section{RESUMEN}

La norma ASTM 876-91 establece un pronóstico de corrosión de la barra de refuerzo del hormigón armado mediante la determinación de potenciales electroquimicos. Este pronóstico se basa en consideraciones termodinámicas, sin tener en cuenta la cinética del proceso de corrosión. Se comparan los resultados obtenidos aplicando esta norma con técnicas electroquimicas (Tafel, Rp, EIS, Ruido Electroquimico) que permiten calcular la velocidad de corrosión en probetas con relaciones agua/cemento 0,4, 0,5 y 0,66 sometidas a niebla salina en condiciones naturales y en inmersión en solución salina al $3 \%$ durante un tiempo de ensayo de 20 meses. Los resultados muestran diferencias entre la aplicación de la norma ASTM y las técnicas electroquímicas aplicadas. Esta diferencia consiste en que las muestras sometidas a inmersión dieron como resultado una mayor probabilidad de ocurrencia del fenómeno de corrosión comparadas con la niebla salina; sin embargo, las técnicas electroquimicas demostraron lo contrario en cuanto a la cinética del proceso. Se compararon los resultados obtenidos por las diferentes técnicas electroquimicas en cuanto a la determinación de la velocidad de corrosión. Es conocido que todas las técnicas trabajan suponiendo corrosión generalizada, a excepción del ruido electroquímico. Mediante el análisis con esta última técnica se pudo calcular el indice de picadura que permitió determinar que la corrosión predominante es la localizada.

\section{SUMMARY}

The ASTM 876-91 standard establishes a corrosion forecast of concrete reinforced bar by measuring the electrochemical potential. This forecast is based on thermodynamic considerations without taking into account the kinetic of the corrosion process. A comparison was made between the results obtained based on this standard and others using electrochemical techniques (Tafel, Rp, EIS, Electrochemical Noise). These techniques allows to obtain the corrosion rate in samples having 0.4, 0.5 and 0.66 water/cement ratios submitted to salt spray outdoors and by immersion in $3 \%$ saline solution during a test time of 20 months. Differences were detected between the results obtained using the ASTM standard and the electrochemical techniques used. The main difference is that samples submitted to immersion shows a higher probability of corrosion than samples submitted to salt spray; however, the electrochemical techniques showed the contrary concerning the corrosion kinetic process.A comparison respecting corrosion rate was also made between the results obtained by the different electrochemical techniques. It is very well known that all electrochemical techniques supposed always general corrosion except electrochemical noise. Using the technique the pitting index can be calculated. It show's that localized corrosion is the most predominant.
PALABRAS CLAVE: potencial, corrosión, técnicas electroquímicas, pronóstico.
KEYWORDS: potential, corrosion, electrochemical techniques, forecast. 


\section{INTRODUCCIÓN}

La corrosión de la barra de refuerzo del hormigón armado constituye un problema en prácticamente la totalidad de los países (1). En Cuba existen numerosas estructuras construidas con este material (edificios, puentes, industrias) afectadas por el fenómeno de la corrosión.

Nuestro país es un archipiélago con un clima caracterizado por tener mas de la mitad del año temperaturas superiores a $25^{\circ} \mathrm{C}$ y humedad relativa alrededor del 80\% (2-3). Dadas su configuración y ubicación geográfica, la influencia de la salinidad llega a casi todo el territorio nacional. Estas condiciones favorecen notablemente el desarrollo de la corrosión de los metales, entre los cuales se incluye la barra de refuerzo del hormigón armado. Se ha determinado que la zona de mayor agresividad corrosiva es la franja de territorio ubicada en la vecindad de la costa norte (3). En la Ciudad de la Habana, situadas a las orillas de esta costa, se encuentran un gran número de estructuras de hormigón armado dañadas por corrosión, lo que es indicativo de la magnitud de este fenómeno.

La norma ASTM (876-91) (4) establece un pronóstico de corrosión de la barra de refuerzo del hormigón armado mediante la determinación de potenciales estacionarios de corrosión. Esta norma se basa en consideraciones termodinámicas (5-6). La determinación de este parámetro ofrece una información cualitativa sobre la magnitud de la corrosión. Actualmente existen técnicas electroquímicas que permiten determinar de forma cuantitativa y no destructiva la velocidad de corrosión instantánea de la barra de refuerzo del hormigón armado (7). Así, es posible con mayor certeza pronosticar el estado de la estructura del acerc de refuerzo.

En este trabajo se hace una comparación entre la técnica cualitativa de evaluación de potenciales para el pronóstico de corrosión según la norma

ASTM (876-91) y la determinación de la velocidad de corrosión por diferentes técnicas electroquímicas, tanto de corriente directa (Tafel, Resistencia de Polarización) como alterna (Espectroscopia de Impedancia

Electroquímica), así como Ruido Electroquímico que es una técnica no perturbadora, o sea, sólo estudia las variaciones de potencial y corriente que genera un metal en un electrolito. Estas cuatro técnicas tienen diferentes bases (8) pero todas permiten calcular la velocidad de corrosión de los metales en un electrolito. De esta forma son muy utilizadas para el control y estudio de la velocidad de corrosión. Cada técnica nos ofrece diferentes informaciones de acuerdo a sus características . En 1997, Videm y Myrdal (9) establecen, utilizando técnicas electroquímicas de

\section{INTRODUCTION}

The corrosion of the reinforcement bar of concrete constitutes a problem in practically all countries (1). In Cuba there are numerous structures builded using this material (buildings, bridges, industries) and affected by the corrosion phenomenon.

Our country is an archipelago with a climate characterized by having more than the half of the year temperatures superior to $25^{\circ} \mathrm{C}$ and relative humidity around the $80 \%(2-3)$. Given their configuration and geographical location, the influence of the salinity reaches to almost all the national territory. These conditions favor notably the development of the corrosion of the metals, including the reinforcement bar of concrete. It has been determined that the zone of major aggressiveness corrosive is the region of territory located in the vicinity of the north coast (3). In the City of the Havana, placed beside this coast, there is a great number of structures of reinforcing concrete damaged for corrosion, as an example of the magnitude of this phenomenon.

The ASTM standard (876-91) (4) establishes a forecast of corrosion of the reinforcement bar of concrete by means of the determination of stationary corrosion potentials. This standard is based on thermodynamic considerations (5-6). The determination of this parameter offers a qualitative information on the magnitude of the corrosion. Actually there are electrochemical techniques that allow to determine in a quantitative form and non destructive the corrosion rate instantaneous of the reinforcement bar of the concrete (7). In this way it is possible with major certainty to have a forecast about the state of the structure of the steel of reinforcement.

A comparison between the qualitative technique of evaluation of potentials for the forecast of corrosion according to the ASTM standard (876-91) and the determination of the corrosion rate for several electrochemical techniques, including those of direct current (Tafel, Resistance of Polarization) as also alternate current (Spectroscopy of Electrochemical Impedance), as well as Electrochemical Noise is made on this paper. This last technique is not perturbative, that is to say, only monitors the variations of potential and current generated for a metal in an electrolyte. These four techniques have different bases (8) but all of them allow to calculate the corrosion rate of the metals in an electrolyte. They are very useful for the control and monitoring the corrosion rate. Each technique offers several information according to its characteristics. In 1997, Videm and Myrdal (9) reported, using electrochemical techniques of direct 
corriente directa, diferencias entre el pronostico de corrosión basado en la norma ASTM con respecto al comportamiento cinético. Igualmente, Elsener y Bohni (5) encontraron diferencias al determinar la corrosión mediante pulsos galvanostáticos y la medición de potenciales. Estos antecedentes ya nos indican la posibilidad de existencia de diferencias entre el pronóstico de corrosión de la norma ASTM y lo determinado mediante técnicas electroquímicas más cuantitativas.

\section{PARTE EXPERIMENTAL}

Se prepararon seis probetas en forma de paralelepípedos $(8 \mathrm{~cm} \mathrm{x} 8 \mathrm{~cm} \mathrm{x} 31 \mathrm{~cm})$ con dos barras de refuerzo paralelas de área libre de $78,6 \mathrm{~cm}^{2}$ cada una (el resto fue cubierto con pintura epoxídica). El espesor del recubrimiento sobre las barras de refuerzo fue de $2 \mathrm{~cm}$ y se confeccionó un conjunto de dos probetas con relaciones agua/cemento de 0,4, 0,5 y 0,66 , respectivamente. Esta relación fue dosificada utilizando el método de O'Reilly (10). Tres muestras representativas de las tres relaciones agua/cemento fueron colocadas en una estación urbana de relativamente baja contaminación a la intemperie, sometidas a una niebla salina de cloruro de sodio al $3 \%$ seis días a la semana. De esta forma se obtiene una agresividad corrosiva similar a una zona costera. Las otras tres se colocaron en inmersión en la misma solución, a temperatura ambiente, durante un tiempo de 20 meses.

Las técnicas electroquímicas utilizadas fueron:

- Medición del potencial estacionario de corrosión y su variación con respecto al tiempo. Se evaluó el potencial a tiempos de $0,2,4,6,8$ y 20 meses. - Curvas de polarización con un barrido de potencial de 100 a $-700 \mathrm{mV}$ con respecto al potencial de corrosión a una velocidad de barrido de $1 \mathrm{mV} / \mathrm{s}$. Cálculo de la velocidad por el método de los intersectos de las rectas de Tafel (8). En todas las técnicas de cálculo de la velocidad de corrosión se realizaron evaluaciones a los mismos tiempos en que se determinaron los potenciales. Se expresan los valores de velocidad de corrosión como corriente de corrosión. Es conocido que estos valores se pueden transformar fácilmente en velocidad de corrosión a partir de la ley de Faraday.

- Determinación de la Resistencia de Polarización (Rp) utilizando una polarización de $\pm 10 \mathrm{mV}$ con respecto al potencial de corrosión. Se calcula la velocidad de corrosión en base a las ecuaciones deducidas para esta técnica (8).

- Espectroscopia de Impedancia Electroquímica (EIS) con una amplitud de la onda alterna de $10 \mathrm{mV}$, al potencial de corrosión, con un barrido de frecuencia current, differences between the prediction based on the ASTM standard concerning the kinetic behavior. Elsener and Bohni (5) found differences upon determining the corrosion by means of galvanostatic pulses and the measurement of potentials. These antecedents already indicate the possibility of existence of differences between the forecast of corrosion based on the ASTM standard and the determination carried out by means of more quantitative electrochemical techniques.

\section{EXPERIMENTAL PART}

Six test probes were made having a parallelepipeds form $(8 \mathrm{~cm} \times 8 \mathrm{~cm} \times 31.5 \mathrm{~cm})$ with two parallel reinforcement bars of free area of $78.6 \mathrm{~cm}^{2}$, each one (the rest of the area was covered with epoxide coating). The coating thickness of concrete on the reinforcement bars was of $2 \mathrm{~cm}$ and a group of two test probes was made with $0.4,0.5$ and 0.66 water/cement relation, respectively. Each relation was made by means of the $O$ 'Reilly method (10). Three representative samples from the water/cement relation were placed in an urban test station of relatively low contamination, subjected to a salt spray of Sodium Chloride 3\% six days every week. By this way, a corrosive aggressiveness similar or higher to a coastal area is obtained. The other three samples were placed immersed in the same solution, exposed to ambient temperature, during a period of 20 months.

The electrochemical techniques used were:

- Stationary corrosion potential measurement and their variation in time. The potential was evaluated at 0,2 , 4, 6, 8 and 20 months.

- Polarization curves were traced with a potential sweep from 100 to $-700 \mathrm{mV}$ respecting to the corrosion potential using a sweep rate of $1 \mathrm{mV} / \mathrm{s}$. The corrosion rate was calculated by the straight line interception method of Tafel (8). Corrosion rate calculation was carried out in all the techniques at the same times in which the potentials were determined. The corrosion rates are expressed as corrosion current values. It is well-known that these values can be easily transformed into corrosion rates by the law of Faraday.

- Polarization Resistance determination (Rp) using a $\pm 10 \mathrm{mV}$ polarization respecting to the corrosion potential. The corrosion rate is calculated based on the equations existing for this technique (8).

- Electrochemical Impedance Spectroscopy (EIS) with an alternating wave amplitude of $10 \mathrm{mV}$, at the corrosion potential, with a frequency sweep of 
de $30.000-0.001 \mathrm{~Hz}$,calculando la Resistencia de Polarización a partir del semicírculo obtenido y con este valor se halla la velocidad de corrosión.

- Determinación del espectro de Ruido

Electroquímico (EN). Se toman 2.048 puntos a velocidad de lectura de 0,5 segundos. Se calcula la velocidad de corrosión a partir de la Resistencia de Ruido calculada entre la desviación standard del ruido de corriente y potencial. La resistencia de ruido se considera igual a la resistencia de polarización. De este valor se calcula la velocidad de corrosión. Se determinó, además, el índice de picaduras, el cual se clasificó de acuerdo a su intervalo calculado entre la desviación estándar de la corriente y la raíz media cuadrática de este mismo parámetro (11).

Las evaluaciones fueron ejecutadas con un equipo Ingles (ACM Modelo Autofast DSP) conectado a un ordenador. El electrodo de referencia utilizado fue el de calomel saturado $\left(\mathrm{Hg} / \mathrm{HgCl}_{2}\right)$ y en los casos necesarios se transformó el valor a cobre/sulfato de cobre $\left(\mathrm{Cu} / \mathrm{CuSO}_{4}\right)$ para clasificar los potenciales de corrosión de acuerdo a la norma ASTM (12). El electrodo de trabajo fue una de las barras de refuerzo, tomando la otra el papel de auxiliar, con excepción del ruido electroquímico donde las dos barras constituyen electrodos de trabajo. Siempre se colocó una esponja fina con agua destilada entre el electrodo de referencia y el concreto en el interior del cual se encuentra la barra de refuerzo para realizar las mediciones. La representatividad de los datos es limitada pues solamente se utilizaron seis probetas.

\section{RESULTADOS}

En la Tabla I se muestran los valores de potencial de corrosión y el tiempo al cual el valor de potencial alcanza el intervalo de $-200 \mathrm{mV}$ a $-350 \mathrm{mV}(50 \%$ de probabilidad de corrosión según la norma ASTM (876-91)) y más negativo que $-350 \mathrm{mV}(90 \%$ de probabilidad de corrosión de acuerdo a la misma norma) junto a los valores de velocidad de corrosión determinados por las diferentes técnicas electroquímicas al mismo tiempo que corta el intervalo (aproximadamente 2 y 8 meses). Como se observa en la tabla, las probetas sometidas a inmersión presentan un potencial inicial mas negativo comparadas con las de niebla salina a la intemperie. Se puede apreciar cómo en el caso de las probetas sometidas a niebla salina sus potenciales alcanzan la zona de $50 \%$ de probabilidad de ocurrencia del fenómeno de corrosión al primer mes para la relación 0,4 agua/cemento, no siendo así para las restantes relaciones bajo la misma condición, donde para 0,5 alcanza dicha zona desde su valor del potencial inicial y a menos de un mes para 0,66 . Sin embargo, las probetas sometidas a inmersión llegan a la zona de $50 \%$ de probabilidad de ocurrencia desde el primer momento
30000-0.001Hz was carried out. The Polarization Resistance was calculated from the semicircle obtained and the corrosion rate was determined using this value. - Electrochemical Noise Spectrum Determination (EN). 2048 points were measured in a reading sequence of 0.5 seconds. The corrosion rate was determined from the Noise Resistance calculated between the standard deviation of the current noise and of the potential. The noise resistance is considered similar to the polarization resistance. The corrosion rate is calculated using this value. The pitting index was also determined and classified according to the interval calculated by the ratio obtained between the standard deviation of the current and the root means square of this same parameter (11).

The evaluations were carried out using an English manufactured instrument (Model ACM Autofast DSP) connected to a computer. The reference electrode used was saturated calomel $(\mathrm{Hg} / \mathrm{HgCl})$ and in the necessary cases the value was transformed to copper/ copper sulfate ( $\mathrm{Cu} / \mathrm{CuSO} \mathrm{S}_{\uparrow}$ ) to classify the corrosion potentials according to the ASTM Standards (12). The working electrode was one of the reinforcement bars, taking the other one the auxiliary role, except for the electrochemical noise where the two bars constitute the working electrodes. A thin sponge with distilled water was always placed between the reference electrode and the concrete with the reinforcement bar inside to carry out the measurements. The statistical significance is limited because only six samples were used.

\section{RESULTS}

The values of potential of corrosion and the time to the which the value of potential reaches the interval of$200 \mathrm{mV}$ to- $350 \mathrm{mV}$ (50\% of probability of corrosion according to the ASTM standard (876-91)) and more negative than $-350 \mathrm{mV}(90 \%$ of probability of corrosion according to the same standard) joins to values corrosion rate to the same time that cuts the interval determined by the several electrochemical techniques (approximately 2 - 8 months) is represented on Table I. As it is observed on the table, the probes subjected to immersion show a more negative initial potential compared with those submitted to salt spray outdoors. In the case of the probes subjected to salt spray their potentials reach the zone of $50 \%$ probability of occurrence of corrosion at the first month for the ratio 0.4 water/cement $(w / c)$, from the first moment to $0.5 \mathrm{w} / \mathrm{c}$ and less than a month for 0.66; however, the probes subjected to immersion reaches the zone of $50 \%$ of probability of occurrence from the first moment of measurement. The major time in that the potential reaches the most negative interval 


\section{TABLA I/TABLE I}

Variación del potencial inicial, tiempo durante el cual el potencial alcanza los valores de -200 y $-350 \mathrm{mV}\left(\mathrm{Cu} / \mathrm{CuSO}_{4}\right)$, así como los valores de velocidad de corrosión a los 28 meses para las distintas relaciones agua/cemento en inmersión y niebla salina por las cuatro técnicas electroquímicas utilizadas.

Changes of the starting potential, the time at which the potential reaches the values of -200 and $-350 \mathrm{mVCu} / \mathrm{CuSO}$ ), as as well as the values of corrosion rates at 2 and 8 months for different water/cement relation under immersion and salt spray conditions for the four electrochemical techniques used

\begin{tabular}{|c|c|c|c|c|c|c|}
\hline \multirow[t]{2}{*}{$\begin{array}{l}\text { Relación agua/cemento } \\
\text { Water/ cement ratio }\end{array}$} & \multicolumn{3}{|c|}{$\begin{array}{l}\text { Niebla salina } \\
\text { Salt spray }\end{array}$} & \multicolumn{3}{|c|}{$\begin{array}{l}\text { Inmersión } \\
\text { Immersion }\end{array}$} \\
\hline & 0.4 & 0.5 & 0.66 & 0.4 & 0.5 & 0.66 \\
\hline $\begin{array}{l}\text { Potencial inicial }(\mathrm{mV}) \\
\text { Starting potential }(\mathrm{mV})\end{array}$ & -159 & -219 & -177 & -277 & -220 & -454 \\
\hline $\begin{array}{l}\text { Corte a }-200 \mathrm{mV} \\
\text { (mes) } \\
\text { Cut at }-200 \mathrm{mV} \\
\text { (month) }\end{array}$ & 1 & 0 & $<1$ & 0 & 0 & 0 \\
\hline $\begin{array}{c}\text { Corte a }-350 \mathrm{mV} \\
\text { (mes) } \\
\text { Cut at }-350 \mathrm{mV} \text { (month) }\end{array}$ & 6-8 & $6-8$ & $<2$ & $6-8$ & $6-8$ & 0 \\
\hline $\begin{array}{l}\text { Ic }\left(\mu \mathrm{A} / \mathrm{cm}^{2} \times 10^{-2}\right) \\
\text { a } 2 \mathrm{meses}(\mathrm{Tafel}) \\
\text { Ic }\left(\mu \mathrm{A} / \mathrm{cm}^{2} \times 10^{-2}\right) \\
\text { at } 2 \text { months (Tafel) }\end{array}$ & 2.07 & 1.70 & 50.8 & 5.05 & 2.52 & 30.4 \\
\hline $\begin{array}{l}\text { Ic }\left(\mu \mathrm{A} / \mathrm{cm}^{2} \times 10^{-2}\right) \\
\text { a } 8 \mathrm{meses}(\mathrm{Tafel}) \\
\text { Ic }\left(\mu \mathrm{A} / \mathrm{cm}^{2} \times 10^{-2}\right) \\
\text { at } 8 \mathrm{months}(\mathrm{Tafel})\end{array}$ & 2.05 & 4.15 & 130 & 6.19 & 11.4 & 45.7 \\
\hline $\begin{array}{l}\text { Ic }\left(\mu \mathrm{A} / \mathrm{cm}^{2} \times 10^{-2}\right) \\
\text { a } 2 \text { meses }(\mathrm{Rp}) \\
\text { Ic }\left(\mu A / \mathrm{cm}^{2} \times 10^{-2}\right) \\
\text { at } 2 \text { months }(R p)\end{array}$ & 3.05 & 3.28 & 15.9 & 13.4 & 5.27 & 44.0 \\
\hline $\begin{array}{l}\text { Ic }\left(\mu \mathrm{A} / \mathrm{cm}^{2} \times 10^{-2}\right) \\
\text { a } 8 \text { meses }(\mathrm{Rp}) \\
\text { Ic }\left(\mu \mathrm{A} / \mathrm{cm}^{2} \times 10^{-2}\right) \\
\text { at } 8 \text { months }(R p)\end{array}$ & 4.99 & 4.54 & 130 & 12.6 & 0.172 & 54.1 \\
\hline $\begin{array}{l}\text { Ic }\left(\mu \mathrm{A} / \mathrm{cm}^{2} \times 10^{-2}\right) \\
\text { a } 2 \text { meses }(\mathrm{EIS}) \\
\text { Ic }\left(\mu \mathrm{A} / \mathrm{cm}^{2} \times 10^{-2}\right) \\
\text { at } 2 \text { months }(E I S)\end{array}$ & 158 & 450 & 685 & 8.45 & 5.87 & 357 \\
\hline $\begin{array}{l}\text { Ic }\left(\mu \mathrm{A} / \mathrm{cm}^{2} \times 10^{-2}\right) \\
\text { a } 8 \text { meses (EIS) } \\
\text { Ic }\left(\mu \mathrm{A} / \mathrm{cm}^{2} \times 10^{-2}\right) \\
\text { at } 8 \text { months (EIS) }\end{array}$ & 262 & 685 & 255 & 15.5 & 704 & 211 \\
\hline $\begin{array}{l}\text { Ic }\left(\mu \mathrm{A} / \mathrm{cm}^{2} \times 10^{-2}\right) \\
\text { a } 2 \text { meses }(\mathrm{EN}) \\
\text { Ic }\left(\mu \mathrm{A} / \mathrm{cm}^{2} \times 10^{-2}\right) \\
\text { at } 2 \text { months }(E N)\end{array}$ & 41.7 & 82.6 & 129 & 8.33 & 1.58 & 20.0 \\
\hline $\begin{array}{l}\text { Ic }\left(\mu \mathrm{A} / \mathrm{cm}^{2} \times 10^{-2}\right) \\
\text { a } 8 \text { meses }(\mathrm{EN}) \\
\text { Ic }\left(\mu \mathrm{A} / \mathrm{cm}^{2} \times 10^{-2}\right) \\
\text { at } 8 \text { months }(E N)\end{array}$ & 59.8 & 160 & 466 & 14.3 & 33.2 & 132 \\
\hline
\end{tabular}


de efectuada las mediciones. El mayor tiempo en que el potencial alcanza el intervalo más negativo establecido en la norma equivale de 6 a 8 meses. A partir de ese momento no se pueden tener ideas sobre cambios de magnitud en el proceso de la corrosión, pero si hacemos un análisis un poco más detallado, las probetas de relaciones agua/cemento de 0,4 y 0,5 en ambas condiciones llegan a la zona de $90 \%$ de probabilidad de ocurrencia casi al mismo tiempo, es decir, entre 6 y 8 meses, en cambio, para la probeta de relación 0,66 a inmersión su potencial de corrosión cae en dicha zona al inicio de la mediciones comparada con su homóloga en niebla salina que llega en menos de 2 meses.

La Tabla II nos presenta los valores de los potenciales de corrosión de la barra de refuerzo a los 20 meses de efectuadas las mediciones. Se observa que se mantienen siempre los valores mas negativos de potencial en el caso de la inmersión.

Las Figuras 1, 2, 3 y 4 muestran el comportamiento de las velocidades de corrosión determinadas por las diferentes técnicas electroquímicas utilizadas con respecto al tiempo. Puede observarse cómo existe una similitud en los valores de corriente de corrosión (Ic) determinados por Tafel, Rp y Ruido Electroquímico, ya que se encuentran aproximadamente en el mismo rango; no siendo así para la técnica de Impedancia, que presenta valores algo superiores a las técnicas anteriormente mencionadas. Se supone que esto pudiera deberse al achatamiento provocado en el semicírculo obtenido producto de la heterogeneidad del sistema hormigón/barra de refuerzo (8). A pesar de que los valores se encuentran en el mismo rango aproximadamente, es de notar en la tabla que la established in the standard is equal to 6 or 8 months. Up to the moment there could not have ideas on changes of magnitude in the corrosion process, but if we make an analysis we can see that the probes of $w / c$ ratio 0.4 and 0.5 in both conditions reaches to the zone of $90 \%$ of probability of corrosion occurrence almost at the same time, that is to say, between 6-8 months. On the other hand, for the probes of relationship 0.66 under immersion their potential of corrosion falls in this zone at the beginning of the measurements comparing with salt spray that reaches this value in less than 2 months.

The values of the corrosion potentials of the reinforcement bar at 20 months of measurements are shown on Table II. There are always more negative values of potentials in the case of samples submitted to immersion.

Figures 1, 2, 3 and 4 show the behaviour of the corrosion rate determined by the electrochemical techniques used concerning time. A similitude in the values of current of corrosion (Ic) determined by Tafel, $R p$ and Electrochemical Noise could be observed. In the case of EIS the values are slightly higher to the techniques previously mentioned. It has been reported that this could be due to the ailment provoked in the semicircle formed by the heterogeneity of the system concrete/bar (8). Although the values fall in the same range approximately, it can be seen on the table that

TABLA II/TABLE II

Valores de los potenciales de corrosión $\mathrm{mV}\left(\mathrm{Cu} / \mathrm{CuSO}_{4}\right)$ de la barra de refuerzo a los 20 meses de ensayo con diferentes relaciones agua/cemento

Corrosion potential values $\mathrm{mV}\left(\mathrm{Cu} / \mathrm{CuSO}_{4}\right)$ of the reinforcement bar after 20 months for different water/cement values.

\begin{tabular}{|c|c|c|c|c|c|c|}
\hline \multirow{2}{*}{$\begin{array}{c}\text { Relación } \\
\text { agua/cemento } \\
\text { Water/cement ratio }\end{array}$} & \multicolumn{3}{|c|}{$\begin{array}{l}\text { Niebla salina } \\
\text { Salt spray }\end{array}$} & \multicolumn{3}{|c|}{$\begin{array}{l}\text { Inmersión } \\
\text { Immersion }\end{array}$} \\
\hline & 0.4 & 0.5 & 0.66 & 0.4 & 0.5 & 0.66 \\
\hline $\begin{array}{c}\text { Potencial } \\
\text { a los } 20 \text { meses }(\mathrm{mV}) \\
\text { Potential } \\
\text { at } 20 \text { months }(\mathrm{mV})\end{array}$ & -466 & -454 & -473 & -550 & -602 & -554 \\
\hline
\end{tabular}




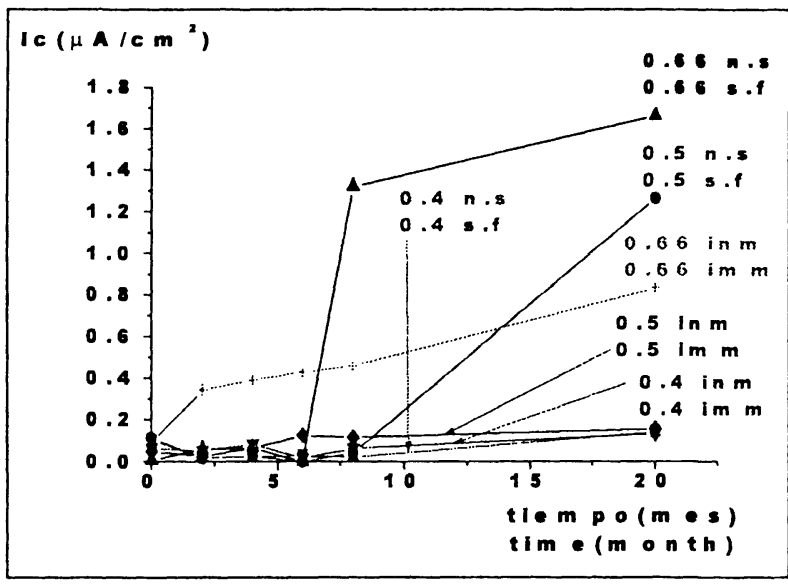

Figura 1.- Comportamiento de las velocidades de corrosión con respecto al tiempo determinadas por el método de Tafel (ns: niebla salina a la intemperie, inm: inmersión en $\mathrm{NaCl}$ al 3\%).

Figure 1.- Behaviour of corrosion rates with the time by the determination Tafels method (sf: salt spray, imm: immersion in $\mathrm{NaCl}$ solution).

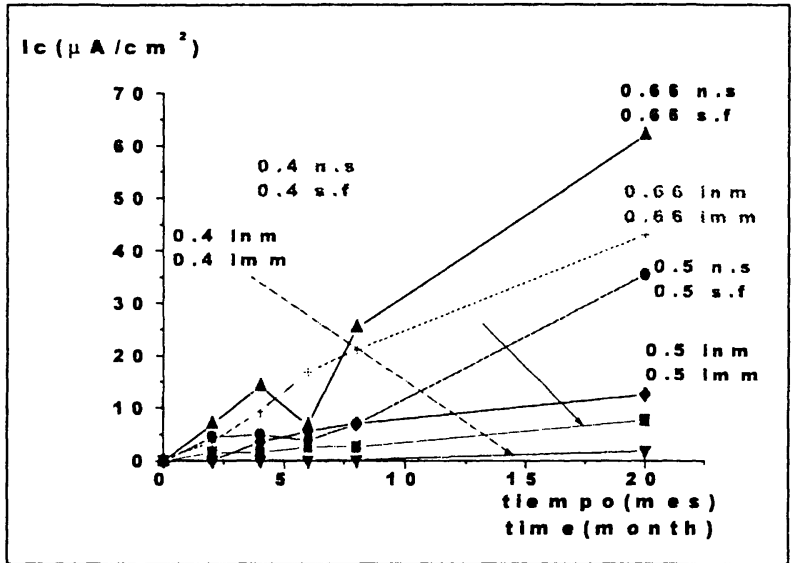

Figura 3.- Comportamiento de las velocidades de corrosión con respecto al tiempo determinadas por el método de EIS (ns: niebla salina a la intemperie, inm: inmersión en $\mathrm{NaCl}$ al 3\%).

Figure 3.- Behaviour of corrosion rates with the time by the determination EIS method (sf: salt spray, imm: immersion in $\mathrm{NaCl}$ solution).

velocidad de corrosión a los dos meses resulta mayor en las condiciones de inmersión cuando se utiliza la técnicas de Tafel $(\mathrm{a} / \mathrm{c}=0,4$ y 0,5$)$, para la relación 0,66 agua/cemento la velocidad de corrosión resulta mayor en la condición de niebla salina a la intemperie, en Rp la velocidad de corrosión es mayor en inmersión $(0,4 ; 0,5$ y 0,66$)$. En el caso de la impedancia siempre la velocidad de corrosión es mayor a la intemperie, lo mismo sucede para el análisis del ruido electroquímico a lo dos meses. A los 8 meses, la velocidad de corrosión es mayor en condiciones de inmersión para las técnicas de Tafel $(0,4$ y 0,5), para 0,66 la velocidad de corrosión resulta mayor en niebla salina, en Rp solamente es mayor la velocidad de corrosión para la relación

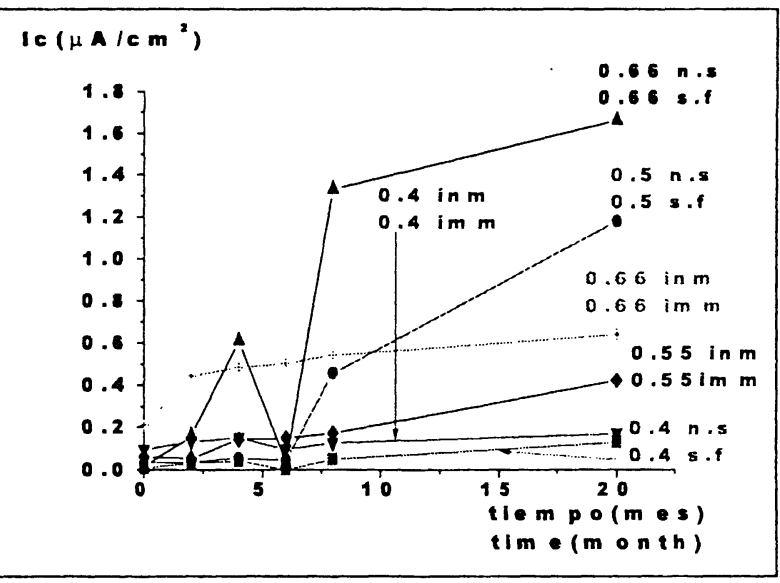

Figura 2.- Comportamiento de las velocidades de corrosión con respecto al tiempo determinadas por el método de $\mathrm{Rp}$ (ns: niebla salina a la intemperie, inm: inmersión en $\mathrm{NaCl}$ al 3\%).

Figure 2.- Behaviour of corrosion rates with the time by the determination $\mathrm{Rp}$ method (sf: salt spray, imm: immersion in $\mathrm{NaCl}$ solution).

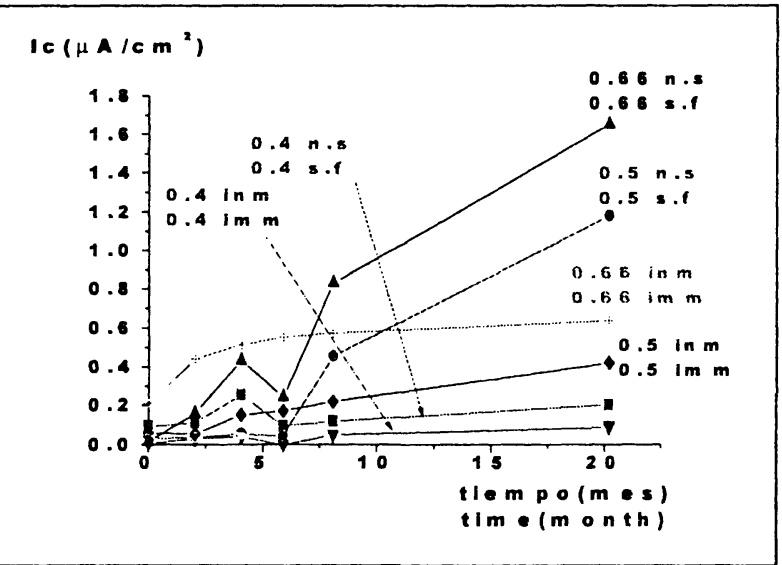

Figura 4.- Comportamiento de las velocidades de corrosión con respecto al tiempo determinadas por el método de EN (ns: niebla salina a la intemperie, inm: inmersión en $\mathrm{NaCl}$ al 3\%).

Figure 4.- Behaviour of corrosion rates with the time by the determination $\mathrm{EN}$ method (sf: salt spray, imm: immersion in $\mathrm{NaCl}$ solution).

corrosion rate at two months is higher under immersion conditions when Tafel technique is used $(w / c=0.40 .5)$; for the relationship $0.66 w / c$ the corrosion rate is higher on samples submitted to salt spray outdoors, using Rp technique, the corrosion rate is higher under immersion $(0.4 ; 0.5$ and 0.66$)$. In the case of EIS always the corrosion rate is higher outdoors, the same happens for the analysis of the electrochemical noise at two months. At 8 months, the corrosion rate is higher in conditions of immersion for the techniques of Tafel (0.4 and 0.5), for 0.66 the corrosion rate results higher in salt spray, in Rp only is higher the corrosion rate for the ratio w/c 0.4 in immersion. Here also the 
agua/cemento 0,4 en inmersión. Aquí también los valores de las velocidades de corrosión determinados por el análisis del ruido electroquímico son mayores en las probetas sometidas a niebla salina a la intemperie con respecto a las de inmersión; sin embargo, para la técnica de impedancia se nota cómo para la relación agua/cemento 0,5 la velocidad de corrosión es mayor en inmersión, en las restantes relaciones la velocidad de corrosión es mayor en las probetas sometidas a niebla salina a la intemperie.

En la Tabla III se indican los valores de desviación estándar del ruido de la corriente ( $\mathrm{Si}$ ), la raíz media cuadrática de la corriente y el índice de picadura a los 20 meses de efectuadas las mediciones. Mediante el análisis del ruido electroquímico se pudo determinar el índice de picadura a través de la desviación estándar de la corriente ( $\mathrm{Si}$ ) entre la raíz media cuadrática de la corriente (Irms) en el último mes (20 meses) de ensayo, donde, de acuerdo a su intervalo de clasificación $(0,1<\mathrm{Ip}<1)$, todas las probetas presentan una corrosión localizada (11). Éste es un parámetro muy importante que nos ofrece esta técnica en comparación con las empleadas anteriormente, ya que nos dice el tipo de corrosión que pudicra ocurrir el la barra de refuerzo del hormigón armado. values of the corrosion rate determined by the analysis of the electrochemical noise are higher in the probes subjected to salt spray outdoors concerning immersion, however for the technique of EIS at ratio $w / c 0.5$ the corrosion is higher in immersion in the others related the corrosion is higher in the probes subjected to salt spray outdoors.

Table III reports values of current noise standard deviations (Si), the root means square of the current and the index of pitting at 20 months of exposure. The index of pitting could be determined through the analysis of the standard deviation of the current (If) electrochemical noise between the root means square of the current (Irms) in the last month (20 months) of testing, where according to their interval of classification $(0.1<1 p<1)$ all the probes show localised corrosion (11). This is a very important parameter offered by this technique in comparison with the others employed.

\section{TABLA III/TABLE III}

Valores de los índices de picadura a los 20 meses de efectuadas las mediciones

Values of the pitting index after 20 months

\begin{tabular}{|c|c|c|c|c|c|c|c|}
\hline $\begin{array}{c}\text { Relación } \\
\text { agua/cemento } \\
\text { niebla salina } \\
\begin{array}{c}\text { Water/cement } \\
\text { ratio } \\
\text { salt spray }\end{array}\end{array}$ & $\mathrm{Si}$ & Irms & $\mathrm{Ip}$ & $\begin{array}{c}\text { Relación a/c } \\
\text { inmersión } \\
\text { Water/cement } \\
\text { ratio } \\
\text { immersion }\end{array}$ & $\mathrm{Si}$ & Irms & Ip \\
\hline 0.4 & $1.728 \times 10^{-7}$ & $1.78 \times 10^{-7}$ & 0.994 & 0.4 & $2.0 \times 10^{-8}$ & $1.999 \times 10^{-8}$ & 0.993 \\
\hline 0.5 & $3.22 \times 10^{-7}$ & $3.24 \times 10^{-7}$ & 0.993 & 0.5 & $8.5 \times 10^{-8}$ & $8.43 \times 10^{-8}$ & 0.996 \\
\hline 0.66 & $6.238 \times 10^{-}$ & $6.337 \times 10^{-10}$ & 0.999 & 0.66 & $1.69 \times 10^{-8}$ & $1.691 \times 10^{-8}$ & 0.999 \\
\hline
\end{tabular}




\section{DISCUSIÓN}

Se puede apreciar que los potenciales de inmersión presentan valores más negativos con respecto a los de niebla salina. Esto, de manera general, indica una mayor probabilidad de ocurrencia del fenómeno de corrosión. Este comportamiento pudiera deberse a una mayor dificultad en la difusión del oxígeno hacia la superficie metálica en condiciones de inmersión completa, lo que hace que el potencial se desplace hacia valores más negativos.

Es posible observar que la mayoría de los valores de velocidad de corrosión instantánea tienden a ser mayores para la condición de niebla salina a la intemperie a los 2 y 8 meses de efectuado el ensayo. Esto contradice la norma ASTM (876-91), ya que, en base a su interpretación, las probetas sometidas a inmersión presentaban una mayor probabilidad de ocurrencia con respecto a las de niebla salina de acuerdo al comportamiento de los potenciales de corrosión.

Se observa también que para las técnicas de corriente directa (Tafel y $\mathrm{Rp}$ ) en las probetas de relación 0,4 agua/cemento no existe una notable diferencia en las velocidades de corrosión entre niebla salina y en inmersión, no siendo así para las relaciones $0,5 \mathrm{y}$ 0,66 donde en niebla salina hay una mayor activación de la velocidad de corrosión con el tiempo respecto a inmersión. Sin embargo, para la técnica de corriente alterna (EIS) y el ruido electroquímico (EN) las probetas sometidas a niebla salina presentan mayor activación de la velocidad de corrosión con el tiempo comparadas con las de inmersión. De forma general se nota más claramente cómo la determinación de la velocidad de corrosión muestra que la norma ASTM (876-91) pronostica la ocurrencia de la corrosión pero no su magnitud, ya que, por ejemplo, las probetas inmersas en solución deberían tener siempre una mayor velocidad de corrosión si coincidiera exactamente el pronóstico de ocurrencia de corrosión según su magnitud. Se reafirma cómo a medida que aumenta la relación agua/cemento aumenta la velocidad de corrosión, ya sea en las probetas sometidas en niebla salina o en inmersión. El comportamiento de la velocidad de corrosión en el tiempo, determinada por las técnicas electroquímicas utilizadas, fue bastante similar, según las figuras 1, 2, 3 y 4. Para llegar a un criterio más exacto sobre la técnica, resulta más fiable realizar una evaluación gravimétrica .

Entre las técnicas electroquímicas utilizadas podemos notar que el ruido electroquímico es la única que nos permite conocer el tipo de corrosión que está ocurriendo. Ésta resulta una ventaja

\section{DISCUSSION}

It could be appreciated that samples show more negative potentials under immersion respecting salt spray outdoors. In a general manner it indicates a higher probability of occurrence of corrosion. This behaviour could be due to a higher difficulty in the diffusion of the oxygen toward the metallic surface in conditions of complete immersion, causing changes in the potential toward more negative values.

Its could observe that the 4 majority of the values of the instantaneous corrosion rate reaches to be higher for the condition of salt spray out doors at 2 and 8 months of exposure. This is not on agreement with ASTM standard (876-91), be cause according to this one, the probes subjected to immersion present a higher probability of ocurrence respecting salt spray based on the behaviour of the corrosion potentials.

\section{It is also observed that for the techniques of direct} current (Tafel and $R p$ ) in the probes of ratios $0.4 \mathrm{w} / \mathrm{c}$ doesn't exist a notable difference in the corrosion rate between salt spray and in immersion, not being so for the ratios 0.5 and 0.66 where in salt spray there is an higher activation of the corrosion rate in the time with concerning immersion.

However, for the technique of alternate current (EIS) and the electrochemical noise (EN) the probes subjected to salt spray introduce higher activation of the corrosion rate with the time compared with the of immersion. From general form note more clearly like the determination of the corrosion rate shows that the ASTM standard (876-91) predicts the occurrence of the corrosion but not their magnitude, since, for example, the probes immerses in solution should always have an old corrosion rate if coincide the forecast of occurrence of corrosion according to their magnitude exactly. Its reaffirmed like an increase the ratios $w / c$ increases the corrosion rate in the probes subjected in salt spray or in immersion. The behaviour of the corrosion rate in the time determined by the electrochemical technical using was quite similar according to the figures 1, 2, 3 and 4. In order to arrive to a more exact criterion on the technique it is more reliable should be carried out an gravimeter evaluation.

In the electrochemical tecchniques used could note that the electrochemical noise is the only that it allow us to know the type of corrosion that is ocurring. This results an important advantage 
importante para esta técnica, además del hecho de que no es causa de perturbación. Su principal dificultad consiste en la interpretación de los espectros, que resulta complicada.

\section{CONCLUSIONES}

- La determinación de potenciales de corrosión, clasificados según la norma ASTM (876-91), no permite conocer con exactitud la magnitud del proceso de corrosión. Para conocer esta magnitud se deben aplicar otras técnicas electroquímicas que ofrecen un valor más cuantitativo y fiable de la velocidad instantánea de corrosión.

- Se comprueba que, a medida que aumenta la relación agua/cemento, aumenta la velocidad de corrosión, tanto en niebla salina como en inmersión.

- No se observan diferencias apreciables en el comportamiento determinado de la velocidad de corrosión en el tiempo para las diferentes técnicas; no obstante, de acuerdo a las características propias de cada una, se obtiene mayor o menor información.

- La diferencia en la magnitud de la corrosión determinada por EIS con respecto a las otras técnicas electroquímicas pudiera deberse al achatamiento del semicírculo provocado por la heterogeneidad del sistema.

- La corrosión de las probetas sometidas a nieblas salina es superior a las que se encuentran en inmersión para altas relaciones agua/cemento. for this technique, besides the fact that is not perturb. Their principal difficulty consists in the interpretation of the spectrum that results complicated.

\section{CONCLUSIONS}

- The determination of corrosion potentials and their classification according to the ASTM standard (876-91) do not allow to know the magnitude of the process of corrosion with accuracy. In order to know this magnitude other electrochemical technical have to be applied.

- It is confirmed that an increase of the ratio water/cement increases the corrosion rate of samples submitted to salt spray outdoors and in complete immersion.

- Appreciable differences in the values of corrosion rate are not observed for the different electrochemical techniques used; however, every techniques offers different information according to the its characteristics.

-The differences in the magnitude of the corrosion determined by EIS respecting other electrochemical techniques could be due to the ailment of the semicircle provoked by the heterogeneity of the system.

- The corrosion of the probes subjected to salt spray outdoors is superior to those under complete immersion for the higher water/cement ratio used.

\section{BIBLIOGRAFÍA}

(1) P. Castro. Corrosión en estructuras de concreto armado, teoría, inspección, vida útil y' reparaciones. Instituto Mexicano del Cemento y del Concreto, A. C., 1998.

(2) A. R. Mendoza, F. Corvo: Outdoor and Indoor atmospheric corrosion of carbon steel, Corrosion Science, vol. 41 (1999), pp. 75. (3) F. Corvo, N. Betancourt, J. C. Díaz, C. Lariot, Y. León, J. Pérez, O. Rodríguez, E. Bricuyet, F. Catala, M. Castro, R. Gonzalez, C. Echevarria. M. Lorente, M.E. Ladron de Guevara: Segunda variante de Mapa Regional de Agresividad Corrosiva de la atmosfera de Cuba. Proceedings Primer Taller Internaciónal de Corrosión. CONACYT-CINVESTAV, Mérida, Yucatan, México, 23-28 marzo, 1992.

(4) ASTM Designation C876-91. Standard Test Method for Half-Cell Potentials of Uncoated Reinforcing Stecl in Concrete.

(5) B. Elsener, H. Bohni: Potential Mapping and Corrosion of Steel in Concrete, "Corrosion Rates of Steel in Concrete, ASTM STP 1065, N. S. Berke. V. Chaker and D. Whiting. Eds., American Society for Testing and Materials. Philadelphia, 1990, pp. 143-156.

(6) J. M. Malo, J. Uruchurtu, Corrosion Mapping of Steel Reinforced in Concrete Exposed to a Galvanizing Process Atmosphere. On line Conferencing Forum.http://www.corrosionsource.com/events/discuss/ic96.html.

(7) J. A. Gonzále\%, S. Feliú, P. Rodríguez, E. Ramírè. C. Alonso, C. Andrade: Some questions on the corrosion of steel in concrete. Part I: when, how and how much steel corrodes. Materials and Structures, Vol. 29. january-february. 1996, pp. 40-46.

(8) J. A. Gonzálcz. Control de la corrosión. Estudio y medida por técnicas electroquímicas, Ed. Bellaterra, 1989

(9) K. Videm. R. Myrdal: Electrochemical Behavior of Steel in Concrete and the Evaluation of the Corrosion Rate. Corrosion Science, Vol. 53, september (1997) pp. $734-742$.

(10) V. O`Reilly, Mćtodo para dosificar mezclas de hormigón. Editorial Científico-Técnica. La Ilabana. 1990.

(11) Shi A.: Electrochemical Noise, acquisition, analysis and applications, http:/www4.esm.psu.edu/people/faculty/shaw/ Electrochemical\%20Noise.ppt

(12) ASTM Designation G3-89 (Reapproved 1994). Standard practice for Conventions Applicable to Electrochemical Measurements in Corrosion Testing. 